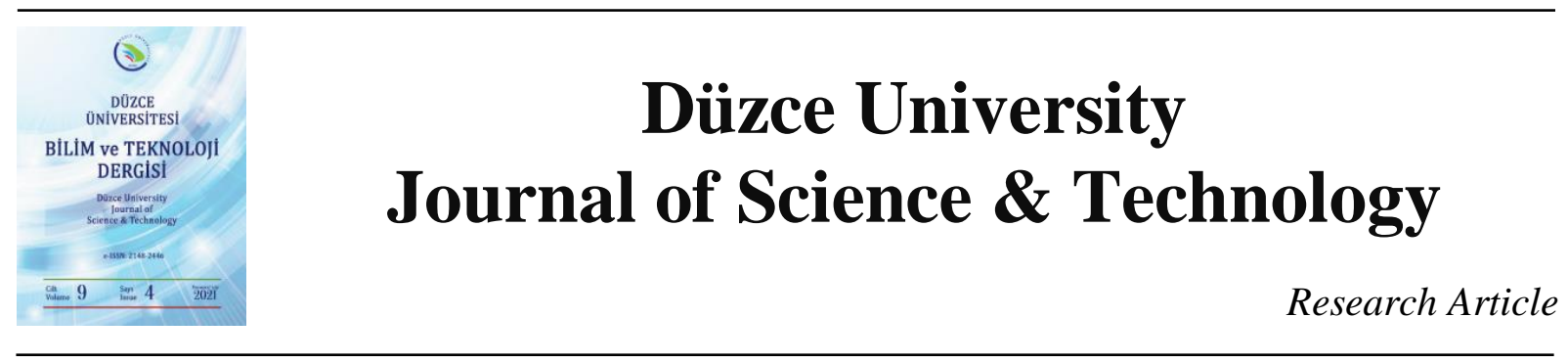

\title{
An Optimization Approach for a Fresh Food Supply Chain: An Application for the Orange Supply Chain Design in Turkey
}

\author{
Gürkan Güven GÜNER a,*, (D) Durdu Hakan UTKU ${ }^{\text {a }}$ \\ ${ }^{a}$ Department of Industrial Engineering, Faculty of Engineering, University of Turkish Aeronautical Association, \\ Ankara, TURKEY \\ * Corresponding author's e-mail address: gguner@thk.edu.tr \\ DOI: 10.29130/dubited.790485
}

\begin{abstract}
The optimization of supply chain problems in various industry areas is crucial in terms of controlling the quality of the products and costs during the supply chain processes. Protecting and controlling the quality of the product in the food supply chain processes while minimizing the cost is a difficult and critical problem in the food industry. In this study, an application of a model that integrates the quality of the food in decision-making on distribution and production in a food supply chain is implemented using real-life data in Turkey. The degradation of quality of products in storage or transportation is usually based on the storage temperature, storage time, and other constants such as activation energy. Therefore, prediction for the quality of food products is a complex task because of the dynamics of storage conditions and various product characteristics. A methodological approach is proposed to model the degradation of food quality in this study. The rate of quality degradation of food products is evaluated by the proposed approach. A mixed-integer programming model is developed for the optimization of distribution and production planning. To solve the problem, GAMS (General Algebraic Modeling System) CPLEX solver is used as an optimization tool. The results of the case study shows that the suggested model in this study is implementable to the problem with acceptable solution time. In addition, the suggested model is adaptable for different types of food supply chains. This study aims to develop a methodological approach that can be used as a guide for decision-makers.
\end{abstract}

Keywords: Food supply chain, optimization, mixed-integer linear programming, food industry

\section{Bir Taze Gıda Tedarik Zinciri için Bir Optimizasyon Yaklaşımı: Türkiye'de Portakal Tedarik Zinciri Tasarımı için Bir Uygulama}

\footnotetext{
ÖZ

Ceșitli endüstri alanlarında tedarik zinciri problemlerinin optimizasyonu, tedarik zinciri ișlemleri süresince ürünlerin kalitesini ve maliyetleri kontrol etmek açısından önemlidir. Gıda tedarik zinciri işlemlerinde maliyeti en kü̧̈üklerken ürünün kalitesini korumak ve kontrol etmek, gıda endüstrisinde zor ve kritik bir problemdir. Bu çalışmada, bir ürünün kalitesini bir gıda tedarik zincirinde dağıtım ve üretim üzerine karar vermede entegre eden bir modelin Türkiye'deki gerçek hayat verilerinin kullanılmasıyla bir uygulaması yapılmıștır. Depolama ve taşımada ürünlerin kalitesinin bozulması genellikle depolama sıcaklığına, depolama zamanına ve aktivasyon enerjisi gibi başka sabitlere bağlıdır. Bu sebeple, depolama kondisyonlarının dinamiklerinden ve çeşitli ürün karakteristiklerinden dolayı, gıda ürünlerinin kalitesinin tahmini kompleks bir iştir. Bu çalışmada gıda kalitesinin bozulmasını modellemek için metodolojik bir yaklaşım önerilmiştir. Gıda ürünlerinin kalite bozulmasının oranı önerilen yaklaşım ile hesaplanmıştır. Dağıtım ve üretim planlamanın optimizasyonu için bir karma-tam sayılı programlama modeli geliştirilmiş̧tir. Problemi çözmek için GAMS (General Algebraic Modeling System) CPLEX
} 
çözücüsü bir optimizasyon aracı olarak kullanılmıştır. Durum çalışmasının sonuçları bu çalışmada önerilen modelin kabul edilebilir bir çözüm zamanı ile probleme uygulanabilir olduğunu göstermiştir. Ayrıca, önerilen model farklı tipteki tedarik zincirlerine uyarlanabilirdir. Bu çalıșma, karar vericiler için bir rehber olarak kullanılabilecek bir metodolojik yaklaşımı geliştirmeyi hedeflemektedir.

Anahtar Kelimeler: Gıda tedarik zinciri, optimizasyon, karma-tam sayılı doğrusal programlama, gıda endüstrisi

\section{INTRODUCTION}

Although its importance, food supply chain management (SCM) is not underlined in the literature very much. One of the reasons can be the complexity of food SCM's network because of the variated characteristics of products and processes. Because of these characteristics, generally, practicability for integration of supply chain in food SCM is limited [1]. The quality of the product is a significant characteristics to consider during the food SCM [2]. The controlling and protecting operations during the supply chain processes increase the food quality, which can variate according to environmental conditions of transportation and storage [3]. It is stated by the Trienekens and Zuurbier that quality assurance can dominate the distribution and production processes in SCM [4].

In the study of Lütke Entrup et al., mixed-integer linear programming (MILP) models to integrate the shelf life of food production are considered [5]. Considering the product quality control, the product perishability is generally underlined in the literature. The perishability can be a random lifetime and a fixed lifetime. However, the degradation of quality does not need to be considered as a fixed lifetime because of continuously variated environmental conditions.

In this study, the modeling approach for quality degradation and modeling approach for quality in production and distribution are presented. Then, the integration of temperature and quality degradation for the SCM is explained. The remaining sections of the study are the literature review, quality degradation model, mathematical model, case study, and conclusions.

\section{A. LITERATURE REVIEW}

Many studies investigate the food SCM problem in the literature. In the study of Sgarbossa and Russo in 2017, it is aimed to provide a methodology for developing new models for closed-loop supply chains [6]. The new models affect the design of the closed-loop supply chain by various sets of logistic providers and resource suppliers. A case study is implemented for a food supply chain in the study. Creating a new sustainable model of the closed-loop supply chain by the use of recover waste from meat processing is the main objective of the study. In the study of Zilberman et al. in 2019, a conceptual system defining the strategies of a company in the food sector for its food supply chain by innovation is presented [7]. The innovating company considers the strategic design of its food supply chain to apply the innovation about the procurement of feedstock, production, and marketing. In the study of Allaoui et al. in 2018, a literature review of operational research techniques to plan sustainable supply chains is presented [8]. A hybrid solution methodology, which includes two stages, is suggested. A selection procedure is implemented by a hybrid multi-criteria decision-making approach. The results obtained from the first stage being used to improve the multi-objective optimization model in the second stage to plan the agro-food supply chain network.

In the study of Grunow et al. in 2011, food quality is integrated into decision making on distribution and production for a food SCM [9]. In the study, a methodologic approach is provided to model the degradation of food quality. This approach is integrated into a MILP model, which is for the planning of distribution and production processes. The suggested model is tested for a case study and results show that the suggested model can be used for the design and distribution planning by considering criteria of 
cost and food quality together. In the study of Chang and Aung, it is underlined that the food industry is becoming more customer-oriented and requires faster response times [10]. In the study, the application of traceability as a tool to help in the assurance of food quality and safety. In addition, this is implemented to get consumer confidence. The study shows extensive information on traceability in terms of quality and safety in the food SCM. The study of Manzini and Accorsi shows a cognitive and general system for the assessment of food SCM and logistics [11]. In the study, it is underlined that SCM and logistics have critical importance in the food industry. The purpose of the suggested approach is designing food SCM to increase sustainability, safety, quality, and efficiency of logistics. A case study is implemented in the study to discuss the efficiency of the suggested approach.

In the study of $\mathrm{Yu}$ and Nagurney, a network-dependent food SCM model under oligopolistic perishability and competition is suggested [12]. The suggested model considers the deterioration of food during the supply chain processes. It is indicated in the study that the reason for considering food deterioration is increasing food freshness (quality) and safety. It is underlined in the study of Chang and Aung that the food SCM is more difficult and complicated compared to other supply chain types because of the perishability and short shelf-life characteristics of foods [13]. The study indicates that cold SCM or temperature-controlled SCM is very beneficial to control the quality of food products. The study suggests techniques to develop the ability to identify an optimal temperature for multi-commodity refrigerated storage. The implemented simulation tests in the study prove that the outputs of the suggested techniques are more accurate in comparison with conventional techniques. In the study of Diabat et al., a model, which analyses different risks included in a food SCM by interpretive structural modelling (ISM), is created [14]. In the study, the different kinds of risks are determined depended on a literature review and expert opinions in the food industry. The suggested model in the study is validated by a case study. Table 1 summarizes the mentioned studies in the literature according to their methodologies and objectives.

Table 1. Literature summary

\section{Reference}

Sgarbossa and Russo, $2017[6]$

\section{Methodology}

Developing new models for closedloop supply chains

\section{Objective}

Creating a new sustainable model of the closed-loop supply chain by the use of recover waste from meat processing

\begin{tabular}{lll}
\hline $\begin{array}{l}\text { Zilberman et al., 2019 } \\
\text { [7] }\end{array}$ & $\begin{array}{l}\text { Considering the strategic design of } \\
\text { the SCM to apply the innovation } \\
\text { about the procurement of feedstock, } \\
\text { production, and marketing }\end{array}$ & $\begin{array}{l}\text { Presenting a conceptual system } \\
\text { defining the strategies of a company } \\
\text { in the food sector for the food supply } \\
\text { chain by innovation }\end{array}$ \\
\hline Allaoui et al., 2018 [8] & $\begin{array}{l}\text { Suggesting a hybrid solution that } \\
\text { includes hybrid multi-criteria } \\
\text { decision-making approach and } \\
\text { multi-objective optimization model. }\end{array}$ & $\begin{array}{l}\text { Planning sustainable supply chains } \\
\text { by a literature review of operational } \\
\text { research techniques }\end{array}$ \\
\hline Grunow et al., 2011 [9] & $\begin{array}{l}\text { An MILP model, which is for the } \\
\text { planning of distribution and } \\
\text { production processes }\end{array}$ & $\begin{array}{l}\text { Modeling the degradation of food } \\
\text { quality, which is integrated into } \\
\text { decision making on distribution and } \\
\text { production for a food SCM, to } \\
\text { minimize the total cost for the short- } \\
\text { term planning horizon }\end{array}$ \\
& $\begin{array}{l}\text { Application of traceability as a tool to } \\
\text { help in the assurance of food quality } \\
\text { and safety, in addition, to get } \\
\text { consumer confidence. }\end{array}$ \\
\hline Chang and Aung, 2014 & $\begin{array}{l}\text { Presenting extensive information on } \\
\text { traceability in terms of quality and } \\
\text { safety in the food SCM }\end{array}$ & $\begin{array}{l}\text { Designing food SCM to increase } \\
\text { sustainability, safety, quality, and } \\
\text { efficiency of logistics }\end{array}$ \\
\hline Manzini and Accorsi, & $\begin{array}{l}\text { Presenting a cognitive and general } \\
\text { system for the assessment of food } \\
\text { SCM and logistics }\end{array}$ &
\end{tabular}


Table 2. (cont.) Literature summary

\begin{tabular}{lll}
$\begin{array}{l}\text { Yu and Nagurney, } \\
2013 \text { [12] }\end{array}$ & $\begin{array}{l}\text { Suggesting a network-dependent } \\
\text { food SCM model }\end{array}$ & $\begin{array}{l}\text { Increasing food freshness (quality) } \\
\text { and safety by considering food } \\
\text { deterioration }\end{array}$ \\
\hline $\begin{array}{l}\text { Chang and Aung, 2014 } \\
{[13]}\end{array}$ & $\begin{array}{l}\text { Suggesting cold (or temperature- } \\
\text { controlled) SCM techniques }\end{array}$ & $\begin{array}{l}\text { Developing the ability to identify an } \\
\text { optimal temperature for multi- } \\
\text { commodity refrigerated storage. }\end{array}$ \\
\hline Diabat et al., 2012 [14] & $\begin{array}{l}\text { Using ISM and determining different } \\
\text { kinds of risk depended on a literature } \\
\text { review and expert opinions }\end{array}$ & $\begin{array}{l}\text { Analyzing different risks included in } \\
\text { a food SCM }\end{array}$ \\
\hline This study & $\begin{array}{l}\text { Suggesting an extended MILP } \\
\text { model, which considers } \\
\text { consumers' perspective }\end{array}$ & $\begin{array}{l}\text { Minimizing the total cost in food } \\
\text { SCM by the integration of } \\
\text { temperature and quality degradation } \\
\text { of products for the long-term } \\
\text { planning horizon }\end{array}$
\end{tabular}

As it is seen in Table 1, this study contributes the literature by suggesting an extended mixed-integer linear programming model, which considers consumers' perspective and minimize the total cost in food SCM by the integration of temperature and quality degradation of products for the long-term planning horizon.

\section{METHODOLOGY}

The quality degradation models and suggested mathematical model are discussed in this section of the article.

\section{A. QUALITY DEGRADATION MODEL}

The quality degradation models, which are introduced in the study of Grunow et al. [9], are used for the considered food product in this study. For a more detailed discussion about quality degradation models, the referred study [9] can be investigated. The degradation of quality for food products in storage usually depends on storage time $t$, storage temperature $T$, and other constants such as gas constant or activation energy. Therefore, it can be evaluated by the following Eq. (1):

$\frac{d q}{d t}=k q^{n}$

In Eq. (1), $q, k$, and $n$ represent the product's quality, the degradation rate based on environmental factors such as temperature, and power factor (order of the reaction) which is for identifying whether the reaction rate is based on the amount of the product's quality, respectively. In general, the value of $n$ is one or zero for first-order reactions and zero-order reactions, respectively. Therefore, $n$ determines the exponential or linear quality decay. For instance, products such as fish and fresh meat, which the degradation of quality based on microbial growth, the degradation of quality follows the first-order reaction. On the other hand, for food products such as vegetables and fresh fruits, the quality degradation follows a zero-order reaction.

Temperature is a critical factor to control the quality of products. The quality degradation rate $k$, is dependent on the Arrhenius equation. Eq. (2) represents this equation:

$k=k_{0} \cdot \exp \left[-E_{a} / R T\right]$ 
In Eq. (2), $k_{0}$ is a constant, $E_{a}$ is the activation energy, $T$ is the absolute temperature, and $R$ is a gas constant. For zero-order and first-order reactions, the quality of a product based on certain storage periods $i=1, \ldots, m$ can be evaluated by the following Eq. (3) and Eq. (4), respectively.

$$
\begin{aligned}
& q=q_{0}-\sum_{i=1}^{m} k_{i} t_{i} \\
& q=q_{0} \cdot \exp \left[-\sum_{i=1}^{m} k_{i} t_{i}\right]
\end{aligned}
$$

When the Eq. (3) and Eq. (4) are substituted for the Eq. (2), which is for the rate of quality degradation, the quality of a product for first-order and zero-order reactions can be seen in Eq. (5) and Eq. (6), respectively.

$$
\begin{aligned}
& q=q_{0}-\sum_{i=1}^{m} k_{0} t_{i} \cdot \exp \left[-E_{a} / R T_{i}\right] \\
& q=q_{0} \cdot \exp \left[-\sum_{i=1}^{m} k_{0} t_{i} \cdot \exp \left[-E_{a} / R T_{i}\right]\right]
\end{aligned}
$$

For zero-order reaction, the quality change $\Delta q$ for a period that has length of $\tau$ and temperature level $T$ can be calculated by the following Eq. (7).

$$
\Delta q(\tau, T)=-k_{0} \tau \cdot \exp \left[-E_{a} / R T\right]
$$

The same Eq. (7) results for the first-order reaction.

\section{B. MATHEMATICAL MODEL}

The following notation and model formulation is used for the suggested mathematical model, which is developed depending on the study of Grunow et al. [9]. The related model is extended through the consumers' perspective [9]. Therefore, the unit cost of the consumer is also considered for products. The purpose is, defining the real consumption amount for each year by minimizing total consumer costs and satisfying the total demand at the same time. In [9], the flow quantities on arcs (between cities) are exactly equal to the total demand of retailer cities. However, in this study, it can be greater than the total demand.

$$
\begin{array}{ll}
\text { Indices: } & \text { node index for storage and production } \\
i & \text { index pair for the arc from node } i \text { to } j \\
i, j & \text { index for quality, } q \in Q \\
q & \text { temperature index, } k \in\{1, \ldots, S\} \\
k & \text { time index (year), } t \in\left\{1-\omega_{\max }, \ldots, H\right\}
\end{array}
$$

$\begin{array}{cl}\text { Sets: } & \\ R & \text { retailer (demand) cities } \\ D & \text { distribution cities } \\ P & \text { production cities } \\ U & \text { storage and production cities, } U=P \cup D \\ N & \text { all nodes, } N=P \cup D \cup R \\ A & \text { all arcs } \\ Q & \text { set of all quality levels } q, Q=\{1, \ldots, B\}\end{array}$


predecessor nodes

$n(i)$

successor nodes

\section{Parameters:}

$q_{\max }$

$q_{i, \min }$

$p_{i, q, t}$

$d_{j, t}$

$s_{i}$

$a_{i, t}$

$f_{i, j, k}$

$\omega_{\max }$

$g_{i, k}^{(1)}$

$g_{i, k}^{(2)}$

$w_{i}$

$\Delta q_{i, k}$

$u_{i, j}$

$\Delta q_{i, j, k}$

$\operatorname{dist}_{i, j}$

$f c_{i, j}$

$c c_{i, t}$

M

the maximum level of quality

the minimum level of quality for products in the city $i$

the production cost of a product in the city $i$ by quality $q$ in $t$ period

demand of city $j$ in period $t$

batch size in the city $i$

capacity of production of the city $i$ in $t$ period

transportation cost of a product on arc $(i, j)$ at $k$ temperature (per period)

maximum lead time of transportation

cost of cooling for city $i$ at temperature level $k$ (per period)

cost of storage for unit product in the city $i$ at $k$ temperature (per period)

cost of waste disposal for unit product that occurs when the quality of product decreases below the needed quality level the in city $i$

degradation of quality for stored products in city $i$ at $k$ temperature (per period)

the transportation duration on $\operatorname{arc}(i, j)$

degradation of quality for transported products on arc $(i, j)$ at $k$ temperature

distances $(\mathrm{km})$ between cities $i$ and $j$

fuel cost of transportation between city $i$ and $j$

the unit consumer cost for the product in the city $i$ at period $t$

a large positive value

\section{Decision Variables:}

$I_{i, q, k, t} \quad$ inventory amount in the city $i$ by $q$ quality and $k$ temperature at the start of $t$ period

$x_{i, j, q, k, t} \quad$ quantities of flow on $\operatorname{arcs}(i, j)$ in $t$ period by $k$ temperature and $q$ quality

$y_{i, q, t}$

$z_{i, k, t}$

$o_{i, j, k, t}$

batch numbers by $q$ quality needed to be manufactured in the city $i$ in $t$ period

$L_{i, t}$

$\Omega_{i, t}$

binary variable that shows whether the city $i$ has $k$ temperature in $t$ period

binary variable shows that whether the equipment of transportation on $\operatorname{arc}(i, j)$ has $k$ temperature in $t$ period $i$

total consumption amount in the city $i$ at $t$ period

the waste amount at city $i$ in $t$ period

\section{B. 1. Model Formulation}

The distribution and production problem can be formulated as the following:

$\min . \quad \sum_{t=1-\omega_{\max }}^{H} \sum_{i \in P} \sum_{q \geq q_{i, \min }} p_{i, q, t} s_{i} y_{i, q, t}+$

$\sum_{t=1-\omega_{\max }}^{H} \sum_{k=1}^{S} \sum_{(i, j) \epsilon A} \sum_{q \geq q_{j, \min }+\Delta q_{i, j, k}} f_{i, j, k} u_{i, j} x_{i, j, q, k, t}+$

$\sum_{t=1-\omega_{\max }}^{H} \sum_{k=1}^{S}\left(\sum_{i \in U} g_{i, k}^{(1)} z_{i, k, t}+\sum_{i \epsilon U} \sum_{q \geq q_{i, m i n}+\Delta q_{i, k}} g_{i, k}^{(2)} I_{i, q, k, t}\right)+$

$\sum_{t=1-\omega_{\max }}^{H} \sum_{i \in U} w_{i} \Omega_{i, t}+\sum_{t=1-\omega_{\max }}^{H} \sum_{i \in R} c c_{i, t} L_{i, t}$

Subject to:

$\sum_{k=1}^{S} I_{i, q, k, t+1}=\sum_{k=1}^{S} I_{i, q+\Delta q_{i, k}, k, t}+s_{i} y_{i, q, t}-$

$\sum_{k=1}^{S} \sum_{j \in\left\{j \in n(i) \mid q \geq q_{j, \min }+\Delta q_{i, j, k}\right\}} x_{i, j, q, k, t}, \quad \forall i \in P, \quad \forall q \in$

$\left\{Q \mid q_{i, \min } \leq q \leq q_{\max }\right\}, \forall t \in\left\{1-\omega_{\max }, \ldots, H\right\}$ 


$$
\begin{aligned}
& \sum_{k=1}^{S} I_{i, q, k, t+1}=\sum_{k=1}^{S} I_{i, q+\Delta q_{i, k}, k, t}+\sum_{k=1}^{S} \sum_{j \in v(i)} x_{j, i, q+\Delta q_{j, i, k}, k, t-u_{j, i}}- \\
& \sum_{k=1}^{S} \sum_{j \in\left\{j \in n(i) \mid q \geq q_{j, \min }+\Delta q_{i, j, k}\right\}} x_{i, j, q, k, t}, \quad \forall i \in D, \forall q \in\left\{Q \mid q_{i, \min } \leq q \leq q_{\max }\right\}, \forall t \in \\
& \left\{1-\omega_{\max }, \ldots, H\right\} \\
& \Omega_{i, t}=\sum_{k=1}^{S} \sum_{q=q_{i, \min }}^{q_{i, \min }+\Delta q_{i, k}-1} I_{i, q, k, t}, \quad \forall i \in U, \quad \forall t \in\left\{1-\omega_{\max }, \ldots, H\right\} \\
& \sum_{k=1}^{S} \sum_{j \in v(i)} \sum_{q \geq q_{i, m i n}} x_{j, i, q+\Delta q_{j, i, k}, k, t-u_{j, i}} \geq d_{i, t}, \quad \forall i \in R, \forall t \in\{1, \ldots, H\} \\
& L_{i, t} \geq d_{i, t}, \quad \forall i \in R, \forall t \in\{1, \ldots, H\} \\
& \sum_{q \geq q_{j, \min }+\Delta q_{i, j, k}} x_{i, j, q, k, t} \leq M o_{i, j, k, t}, \quad \forall(i, j) \in A, \forall k \in\{1, \ldots, S\}, \forall t \in\{1- \\
& \left.\omega_{\max }, \ldots, H\right\} \\
& \sum_{q \geq q_{j, \min }+\Delta q_{i, j, k}} x_{i, j, q, k, t} \geq o_{i, j, k, t}, \forall(i, j) \in A, \forall k \in\{1, \ldots, S\}, \forall t \in\left\{1-\omega_{\max }, \ldots, H\right\} \\
& \sum_{k=1}^{S} o_{i, j, k, t} \leq 1, \quad \forall(i, j) \in A, \quad \forall t \in\left\{1-\omega_{\max }, \ldots, H\right\} \\
& I_{i, q, k, t} \leq M z_{i, k, t}, \quad \forall i \in U, \forall q \in\left\{Q \mid q \geq q_{i, \min }\right\}, \forall k \in\{1, \ldots, S\}, \quad \forall t \in\{1- \\
& \left.\omega_{\max }, \ldots, H\right\} \\
& \sum_{k=1}^{S} z_{i, k, t}=1, \quad \forall i \in U, \quad \forall t \in\left\{1-\omega_{\max }, \ldots, H\right\} \\
& \sum_{q \geq q_{i, \min }} s_{i} y_{i, q, t} \leq a_{i, t}, \forall i \in P, \forall t \in\left\{1-\omega_{\max }, \ldots, H\right\} \\
& I_{i, q, k, t} \geq 0, \forall i \in U, \forall q \in\left\{Q \mid q \geq q_{i, \min }\right\}, \quad \forall k \in\{1, \ldots, S\}, \forall t \in\{1- \\
& \left.\omega_{\max }, \ldots, H\right\} \\
& x_{i, j, q, k, t} \geq 0, \forall(i, j) \in A, \forall q \in\left\{Q \mid q \geq q_{i, \min }\right\}, \forall k \in\{1, \ldots, S\}, \forall t \in\{1- \\
& \left.\omega_{\max }, \ldots, H\right\} \\
& o_{i, j, k, t} \in\{0,1\}, \quad \forall(i, j) \in A, \forall k \in\{1, \ldots, S\}, \forall t \in\{1- \\
& \left.\omega_{\max }, \ldots, H\right\} \\
& z_{i, k, t} \in\{0,1\}, \quad \forall i \in U, \forall k \in\{1, \ldots, S\}, \forall t \in\left\{1-\omega_{\max }, \ldots, H\right\} \\
& y_{i, q, t} \geq 0 \text { and integer, } \forall i \in P, \forall q \in\left\{Q \mid q \geq q_{i, \min }\right\}, \forall t \in\left\{1-\omega_{\max }, \ldots, H\right\}
\end{aligned}
$$

The objective function (8) of the mathematical model minimizes the total cost, which includes the cost of production, storage, transportation, and cooling. The objective function also minimizes the total cost of consumers in each city for each period compared to the model in the study [9]. Constraints (9) and (10) provide inventory balances for production and distribution cities, respectively. Constraint (11) calculates the waste amount of products, which quality is between certain intervals. In addition, this constraint provides that when the quality is less than a certain level, the inventory is zero. Constraint (12) is for satisfying requirements of quality and demand for retailer cities. The total transported amount of product can be more than the total demand of the retailer city. Constraint (13) satisfies that the total consumption amount should be greater or equal to total demand. Constraints (14), (15), and (16) are for the requirement of transportation equipment and selecting the temperature of the transportation equipment. Constraint (15) also increases the solution efficiency. It provides that binary variables for transportation equipment become zero when there is no flow between corresponding cities. Constraint (17) determines the inventory under different temperatures. Constraint (18) selects only one temperature level for each storage city because the facility in each storage city should be operated at a single temperature level. Therefore, it is required to use the binary variable $z_{i, k, t}$ for the assignment of only 
one temperature level $k$ to the storage city $i$. Constraint (19) is for production capacity. Finally, constraints (20) - (24) are non-negativity and integer constraints.

\section{CASE STUDY}

The orange supply chain processes in Turkey are considered in this study. A total of 17 production cities of orange and a total of 4 retailers (or demand) cities are considered. There are also 2 distribution cities between production and retailer cities. It is considered that the direct transportations between production and retailer cities are possible. The planning horizon $(H)$, which is the upper limit of time index $t$, is future 6 years in this study and a one-time period $t$, in the mathematical model means one year. For this purpose, firstly, the real data of the past 6 years are collected and then, the forecasted values for future 6 years are estimated. These forecasted values are used for the case study. The past unit costs (TL/kg) of orange producers and consumers between years 2014 and 2019 [15] and the forecasted cost values for years between 2020 and 2025 in Turkey are shown in Table 2 and Table 3, respectively. The forecasted values are estimated depending on the past values in Table 2. Because the past cost values approximately have a very consistent and increasing trend except the fall in year 2016 for both costs and there is no seasonality, the forecasted cost values are estimated by a time series trend analysis considering linear trend model in Minitab.

Table 2. Unit cost of orange producer and consumer for different years (TL/kg)

\begin{tabular}{ccccccc}
\hline \multicolumn{1}{c}{ year } & $\mathbf{2 0 1 4}$ & $\mathbf{2 0 1 5}$ & $\mathbf{2 0 1 6}$ & $\mathbf{2 0 1 7}$ & $\mathbf{2 0 1 8}$ & $\mathbf{2 0 1 9}$ \\
\hline producer & 0.53 & 0.67 & 0.60 & 0.71 & 0.80 & 1.05 \\
\hline consumer & 1.78 & 2.28 & 2.07 & 2.79 & 3.07 & 4.19 \\
\hline
\end{tabular}

Table 3. Forecasted cost of orange producer and consumer for different years (TL/kg)

\begin{tabular}{ccccccc}
\hline year & $\mathbf{2 0 2 0}$ & $\mathbf{2 0 2 1}$ & $\mathbf{2 0 2 2}$ & $\mathbf{2 0 2 3}$ & $\mathbf{2 0 2 4}$ & $\mathbf{2 0 2 5}$ \\
\hline producer & 1.03 & 1.12 & 1.21 & 1.30 & 1.39 & 1.47 \\
\hline consumer & 4.21 & 4.64 & 5.07 & 5.50 & 5.94 & 6.37 \\
\hline
\end{tabular}

Table 4 shows the past total orange (Washington oranges, Yafa oranges and other oranges) production (kg) of 17 producer cities between years 2014 and 2019 [16].

Table 4. Total orange production of cities between 2014 and 2019 (kg)

\begin{tabular}{lllllll}
\hline City & $\mathbf{2 0 1 4}$ & $\mathbf{2 0 1 5}$ & $\mathbf{2 0 1 6}$ & $\mathbf{2 0 1 7}$ & $\mathbf{2 0 1 8}$ & $\mathbf{2 0 1 9}$ \\
\hline Adana & $390,294,000$ & $410,824,000$ & $435,657,000$ & $407,178,000$ & $416,102,000$ & $370,224,000$ \\
\hline Antalya & $500,663,000$ & $496,487,000$ & $504,655,000$ & $549,681,000$ & $525,821,000$ & $508,903,000$ \\
\hline Artvin & 763,000 & 763,000 & 666,000 & 674,000 & 377,000 & 347,000 \\
\hline Aydın & $55,505,000$ & $55,779,000$ & $53,105,000$ & $55,416,000$ & $61,544,000$ & $61,026,000$ \\
\hline Balıkesir & 420,000 & 350,000 & 350,000 & 382,000 & 422,000 & 228,000 \\
\hline Burdur & 13,000 & 13,000 & 13,000 & 15,000 & 16,000 & 16,000 \\
\hline Giresun & 135,000 & 132,000 & 126,000 & 118,000 & 101,000 & 83,000 \\
\hline Hatay & $290,220,000$ & $313,767,000$ & $316,019,000$ & $342,187,000$ & $319,026,000$ & $294,602,000$ \\
\hline K.maraş & $1,066,000$ & 566,000 & 472,000 & 510,000 & 456,000 & 317,000 \\
\hline Kastamonu & 1,000 & 1,000 & 1,000 & 1,000 & 1,000 & 1,000 \\
\hline Mersin & $276,488,000$ & $276,702,000$ & $275,147,000$ & $284,574,000$ & $288,547,000$ & $215,972,000$ \\
\hline Muğla & $229,571,000$ & $230,842,000$ & $249,930,000$ & $296,617,000$ & $265,610,000$ & $232,912,000$ \\
\hline Ordu & 50,000 & 69,000 & 77,000 & 84,000 & 82,000 & 72,000 \\
\hline Osmaniye & $32,982,000$ & $29,074,000$ & $12,262,000$ & $10,912,000$ & $20,308,000$ & $13,861,000$ \\
\hline Rize & 570,000 & 569,000 & 572,000 & 638,000 & 629,000 & 577,000 \\
\hline Trabzon & 378,000 & 331,000 & 335,000 & 369,000 & 341,000 & 317,000 \\
\hline İzmir & 556,000 & 529,000 & 613,000 & 644,000 & 617,000 & 542,000 \\
\hline
\end{tabular}


Table 5 shows the forecasted total orange (Washington oranges, Yafa oranges and other oranges) production $(\mathrm{kg})$ of 17 producer cities between years 2020 and 2025. The forecasted production values are estimated based on the production values in Table 4 . The past production values of most of the cities in Table 4 do not have an increasing or decreasing trend and seasonal component in general. Therefore, it is approved to use a non-seasonal autoregressive integrated moving average (ARIMA) model, which is used in time series analysis. The ARIMA parameters $p$ (order of the autoregressive model), $d$ (degree of differencing), and $q$ (order of the moving average model) are determined according to past data of each city. After the comparisons between the results gathered from using different ARIMA parameters, it is approved to use $\operatorname{ARIMA}(2,0,2)$ for the most of the cities. The forecasted values are estimated by implementing ARIMA model in RStudio, which is an integrated development environment for $\mathrm{R}$ programming language. The more detailed information for the ARIMA models and the time series analyses in the R programming language can be found in the referenced books [17] and [18], respectively.

Table 5. Forecasted total orange production of cities between 2020 and 2025 ( kg)

\begin{tabular}{lllllll}
\hline City & $\mathbf{2 0 2 0}$ & $\mathbf{2 0 2 1}$ & $\mathbf{2 0 2 2}$ & $\mathbf{2 0 2 3}$ & $\mathbf{2 0 2 4}$ & $\mathbf{2 0 2 5}$ \\
\hline Adana & $409,293,465$ & $428,618,706$ & $422,409,176$ & $402,723,111$ & $393,286,518$ & $401,881,296$ \\
\hline Antalya & $493,588,461$ & $509,884,249$ & $533,084,835$ & $533,793,761$ & $512,567,484$ & $497,301,647$ \\
\hline Artvin & 372,965 & 477,430 & 620,397 & 736,973 & 774,454 & 716,147 \\
\hline Aydın & $55,815,515$ & $53,104,442$ & $54,467,463$ & $57,030,277$ & $58,131,944$ & $57,468,104$ \\
\hline Balıkesir & 547,241 & 225,833 & 428,153 & 392,512 & 293,178 & 450,896 \\
\hline Burdur & 14,888 & 13,447 & 12,665 & 13,080 & 14,402 & 15,711 \\
\hline Giresun & 87,145 & 90,684 & 93,705 & 96,283 & 98,484 & 100,363 \\
\hline Hatay & $299,270,606$ & $321,402,468$ & $334,614,748$ & $323,934,869$ & $303,714,144$ & $298,543,999$ \\
\hline K.maraş & 365,678 & 543,405 & 659,644 & 684,367 & 662,043 & 636,599 \\
\hline Kastamonu & 1,000 & 1,000 & 1,000 & 1,000 & 1,000 & 1,000 \\
\hline Mersin & $256,504,425$ & $258,402,254$ & $258,491,115$ & $258,495,276$ & $258,495,471$ & $258,495,480$ \\
\hline Muğla & $225,752,275$ & $259,173,798$ & $285,744,246$ & $269,792,059$ & $234,049,242$ & $227,319,893$ \\
\hline Ordu & 68,242 & 67,228 & 66,707 & 66,439 & 66,302 & 66,231 \\
\hline Osmaniye & $13,404,245$ & $22,934,324$ & $23,572,319$ & $19,997,555$ & $17,506,310$ & $17,445,356$ \\
\hline Rize & 552,986 & 582,799 & 626,957 & 628,453 & 587,018 & 557,278 \\
\hline Trabzon & 391,424 & 322,186 & 329,448 & 386,382 & 318,599 & 338,003 \\
\hline İzmir & 547,196 & 619,611 & 650,637 & 594,231 & 535,745 & 562,783 \\
\hline
\end{tabular}

The orange consumption per capita in the 2017/2018 and 2018/2019 seasons are $10.8 \mathrm{~kg}$ [19] and 13.5 $\mathrm{kg}$ [20], respectively, in Turkey. There is $25 \%$ increase between the seasons but this increase can be variated for each consecutive year. Because there is not enough data and it is very difficult to forecast the yearly orange consumption per capita, it is assumed that this value is $13.5 \mathrm{~kg}$ for the each future 6 year and probable yearly variations are neglected. Multiplying this ratio with the total forecasted population of four retailer cities in Table 7 [21], total forecasted orange demand $(\mathrm{kg})$ of retailer cities for different years is calculated and shown in Table 8. The total forecasted populations of the cities are estimated depending on the past populations in Table 6. Because the past populations approximately have a very consistent and increasing trend and there is no seasonality, the forecasted populations are estimated by a time series trend analysis considering linear trend model in Minitab.

Table 6. Total populations of cities

\begin{tabular}{ccccccc}
\hline City & $\mathbf{2 0 1 4}$ & $\mathbf{2 0 1 5}$ & $\mathbf{2 0 1 6}$ & $\mathbf{2 0 1 7}$ & $\mathbf{2 0 1 8}$ & $\mathbf{2 0 1 9}$ \\
\hline Ankara & $5,150,072$ & $5,270,575$ & $5,346,518$ & $5,445,026$ & $5,503,985$ & $5,639,076$ \\
\hline İstanbul & $14,377,018$ & $14,657,434$ & $14,804,116$ & $15,029,231$ & $15,067,724$ & $15,519,267$ \\
\hline İzmir & $4,113,072$ & $4,168,415$ & $4,223,545$ & $4,279,677$ & $4,320,519$ & $4,367,251$ \\
\hline Bursa & $2,787,539$ & $2,842,547$ & $2,901,396$ & $2,936,803$ & $2,994,521$ & $3,056,120$ \\
\hline
\end{tabular}


Table 7. Total forecasted populations of cities

\begin{tabular}{ccccccc}
\hline City & $\mathbf{2 0 2 0}$ & $\mathbf{2 0 2 1}$ & $\mathbf{2 0 2 2}$ & $\mathbf{2 0 2 3}$ & $\mathbf{2 0 2 4}$ & $\mathbf{2 0 2 5}$ \\
\hline Ankara & $5,716,918$ & $5,809,597$ & $5,902,275$ & $5,994,954$ & $6,087,633$ & $6,180,312$ \\
\hline İstanbul & $15,625,855$ & $15,830,633$ & $16,035,411$ & $16,240,189$ & $16,444,967$ & $16,649,745$ \\
\hline İzmir & $4,423,747$ & $4,474,700$ & $4,525,652$ & $4,576,605$ & $4,627,557$ & $4,678,510$ \\
\hline Bursa & $3,103,244$ & $3,155,651$ & $3,208,058$ & $3,260,464$ & $3,312,871$ & $3,365,278$ \\
\hline
\end{tabular}

Table 8. Total forecasted orange demand $(\mathrm{kg})$ of retailer cities for different years

\begin{tabular}{ccccccc}
\hline City & $\mathbf{2 0 2 0}$ & $\mathbf{2 0 2 1}$ & $\mathbf{2 0 2 2}$ & $\mathbf{2 0 2 3}$ & $\mathbf{2 0 2 4}$ & $\mathbf{2 0 2 5}$ \\
\hline Ankara & $77,178,393$ & $78,429,559$ & $79,680,712$ & $80,931,879$ & $82,183,045$ & $83,434,212$ \\
\hline İstanbul & $210,949,042$ & $213,713,545$ & $216,478,048$ & $219,242,551$ & $222,007,054$ & $224,771,557$ \\
\hline İzmir & $59,720,584$ & $60,408,450$ & $61,096,302$ & $61,784,167$ & $62,472,019$ & $63,159,885$ \\
\hline Bursa & $41,893,794$ & $42,601,288$ & $43,308,783$ & $44,016,264$ & $44,723,758$ & $45,431,253$ \\
\hline
\end{tabular}

Table 9 shows the total forecasted cost (TL) of producing orange in producer cities for different years. It is calculated by multiplying the forecasted producer cost values in Table 3 and the forecasted production amounts in Table 5.

Table 9. Total forecasted cost of producing orange in producer cities for different years (TL)

\begin{tabular}{lllllll}
\hline City & $\mathbf{2 0 2 0}$ & $\mathbf{2 0 2 1}$ & $\mathbf{2 0 2 2}$ & $\mathbf{2 0 2 3}$ & $\mathbf{2 0 2 4}$ & $\mathbf{2 0 2 5}$ \\
\hline Adana & $421,572,269$ & $480,052,951$ & $511,115,103$ & $523,540,044$ & $546,668,260$ & $590,765,505$ \\
\hline Antalya & $508,396,115$ & $571,070,359$ & $645,032,650$ & $693,931,889$ & $712,468,803$ & $731,033,421$ \\
\hline Artvin & 384,154 & 534,722 & 750,680 & 958,065 & $1,076,491$ & $1,052,736$ \\
\hline Aydın & $57,489,980$ & $59,476,975$ & $65,905,630$ & $74,139,360$ & $80,803,402$ & $84,478,113$ \\
\hline Balıkesir & 563,658 & 252,933 & 518,065 & 510,266 & 407,517 & 662,817 \\
\hline Burdur & 15,335 & 15,061 & 15,325 & 17,004 & 20,019 & 23,095 \\
\hline Giresun & 89,759 & 101,566 & 113,383 & 125,168 & 136,893 & 147,534 \\
\hline Hatay & $308,248,724$ & $359,970,764$ & $404,883,845$ & $421,115,330$ & $422,162,660$ & $438,859,679$ \\
\hline K.maraş & 376,648 & 608,614 & 798,169 & 889,677 & 920,240 & 935,801 \\
\hline Kastamonu & 1,030 & 1,120 & 1,210 & 1,300 & 1,390 & 1,470 \\
\hline Mersin & $264,199,558$ & $289,410,524$ & $312,774,249$ & $336,043,859$ & $359,308,705$ & $379,988,356$ \\
\hline Muğla & $232,524,843$ & $290,274,654$ & $345,750,538$ & $350,729,677$ & $325,328,446$ & $334,160,243$ \\
\hline Ordu & 70,289 & 75,295 & 80,715 & 86,371 & 92,160 & 97,360 \\
\hline Osmaniye & $13,806,372$ & $25,686,443$ & $28,522,506$ & $25,996,822$ & $24,333,771$ & $25,644,673$ \\
\hline Rize & 569,576 & 652,735 & 758,618 & 816,989 & 815,955 & 819,199 \\
\hline Trabzon & 403,167 & 360,848 & 398,632 & 502,297 & 442,853 & 496,864 \\
\hline İzmir & 563,612 & 693,964 & 787,271 & 772,500 & 744,686 & 827,291 \\
\hline
\end{tabular}

In this study, a retailer city Ankara and a producer city Antalya are considered as two distribution cities. It means that all of the 17 producer cities can transport the products to these cities before transporting them to the target retailer city. However, using these distribution cities is not an obligation. In other words, direct transportations between production and retailer cities can be made also.

Color and firmness are two significant elements for identifying the quality of oranges. Depending on the study of Grunow et al. in 2011, the shelf life decreases from three to two weeks (21 to 14 days) when temperature increases from 7.2 to $10{ }^{\circ} \mathrm{C}$ for the peppers [9]. The same study indicates that quality degradation of the vegetables and fresh fruits follow a zero-order reaction (Eq. 1). Therefore, the quality of the shelf life of oranges is a linear function. The orange shelf life is calculated by considering the mentioned information about peppers in the study of Grunow et al. [9]. Therefore, the obtained shelflife increase for oranges for a unit temperature decrease is $(3-2) / 7(10-7.2)=2.5$ days $/ 1{ }^{\circ} \mathrm{C}$. The quality is affected by storage temperatures in production/distribution centers and transportation temperatures between production and distribution/retailer centers. In this study, the chosen temperatures $(k)$ for the 
case study are between $2,4,6,8$ or $10^{\circ} \mathrm{C}$. Therefore, the $S$ value, which is the upper limit of the temperature index $k$, means $10{ }^{\circ} \mathrm{C}$.

In the study of Grunow et al., the planning horizon, which includes the transportation lead time, is 14 days and the considered transportation lead time is 3 days [9]. It is important to determine the quality level to distinguish different temperature levels. In the study of Grunow et al., the quality degradation is integer value per day and the determined quality range is between 600 and 750 for considering a detailed and sufficient scale range [9]. In this study, we try to consider a longer planning horizon. The planning horizon in this study is 6 years and a one-time period $t$, in the mathematical model means one year. The considered maximum lead time of transportation between cities is 0.0082 years ( 3 days) in this study.

In this study, decimal quality degradation values are considered and the considered quality range is between 1.6438 and 2.0547. The evaluated shelf life values and quality degradations for each of the determined temperatures are in Table 10.

Table 10. Calculated quality degradation and shelf life for different temperatures

\begin{tabular}{lccccc}
\hline Temperatures $\left({ }^{\circ} \boldsymbol{C}\right)$ & $\mathbf{2}$ & $\mathbf{4}$ & $\mathbf{6}$ & $\mathbf{8}$ & $\mathbf{1 0}$ \\
\hline Shelf life $($ days) & 34 & 29 & 24 & 19 & 14 \\
\hline Shelf life (years) & 0.09 & 0.07 & 0.06 & 0.05 & 0.03 \\
\hline Degradation of quality per day $(\Delta q)$ & 11 & 13 & 16 & 20 & 27 \\
\hline Degradation of quality per year $(\Delta q)$ & 0.03 & 0.03 & 0.04 & 0.05 & 0.07 \\
\hline
\end{tabular}

It is important to convert the quality requirements of the retailer cities to quality levels. It is assumed in this study that the quality requirement of Ankara and İstanbul is $85 \%$ and the quality requirement of the Bursa and İzmir is $80 \%$. Because the $100 \%$ quality means 2.0547 quality level in this study, $85 \%$, and $80 \%$ quality requirements mean 1.7464 and 1.6437 , respectively. The range of quality values in the model is considered by 0.1 intervals. Therefore, the considered quality values $(q)$ in the model are 1.64 , $1.74,1.84,1.94$ and 2.04 . The $B$ value, which is the upper limit of $Q$ (set of all quality levels $q$ ), is 1 because there is one quality set in this study. To evaluate relative cooling costs during storage and transportation of oranges, a formula for the coefficient of performance suggested in the study of Wang is considered [22]. Because the cooling cost can be evaluated by considering the thermal characteristics of cooling processes. Therefore, the refrigeration process should be formulated. Eq. (25) shows the calculation of the coefficient of performance $(C P)$ by neglecting energy losses [22].

$$
C P=\frac{T L}{T H-T L}
$$

In Eq. (25), $T L$ and $T H$ are lower and higher temperatures (measured in Kelvin), respectively. Lower and higher temperatures mean cooling and environment temperatures, respectively. For instance, if $T L$ $=2{ }^{\circ} \mathrm{C}(275 \mathrm{~K})$ and $T H=20^{\circ} \mathrm{C}(293 \mathrm{~K}), C P=15.3$ units. This means that the coolant can absorb 15.3 units of heat for each energy unit. Therefore, higher electrical energy is required for low-temperature levels. However, in real, some other factors such as system or compressor efficiency effect the $C P$ [22]. Therefore, $C P$ can be calculated by the following Eq. (26).

$$
C P=\eta_{t}\left(\frac{T L}{T H-T L}\right)
$$

In Eq. (26), $\eta_{t}$ means the system efficiency. It is assumed that the value of $\eta_{t}$ variates between $50 \%$ and $70 \%$. It is expected that $\eta_{t}$ is lower for the lower temperatures and by assuming $5 \%$ efficiency losses for each two degree decrease, the considered $\eta_{t}$ values for $2,4,6,8$ and 10 degrees are $50 \%, 55 \%, 60 \%$, $65 \%$ and $70 \%$, respectively. Therefore, $C P=(15.3)(0.50)=7.65$ for $2{ }^{\circ} \mathrm{C}$ degree. In this study, a fixed unit of electrical energy is assumed to make cooling costs approximately proportional to the consumed amount of energy. It is assumed that electrical energy cost at $2{ }^{\circ} \mathrm{C}$ is $1 \mathrm{TL}$. In this way, the relative 
cooling cost at high-temperature levels is evaluated with the multiplication of the cost and $C P$ value. The environment (higher) temperature is considered as $20^{\circ} \mathrm{C}(293 \mathrm{~K})$. For example, by using $C P=7.65$ at $2{ }^{\circ} \mathrm{C}$ and $C P=(277 \mathrm{~K} /(293-277 \mathrm{~K}))(0.55)=(17.3)(0.55)=9.51$ at $4{ }^{\circ} \mathrm{C}$, the obtained cost ratio is $7.65 / 9.51=0.80$. Table 11 shows other calculated cost ratios by using $2^{\circ} \mathrm{C}$ as a reference for different temperature levels. The $\operatorname{revc}_{k}$ (relative cooling cost) values are multiplied with distances $(\mathrm{km})$ between cities $\left(\right.$ dist $\left._{i, j}\right)$ and added to the fuel cost of transportation $\left(f c_{i, j}\right)$ to evaluate the cost parameters at different temperature levels $\left(f_{i, j, k}\right)$. Therefore, $f_{i, j, k}=\operatorname{revc}_{k} d i s t_{i, j}+f c_{i, j}$.

Table 11. Relative cooling costs for different temperatures

\begin{tabular}{lccccc}
\hline Temperature $\left({ }^{\circ} \mathbf{C}\right)$ & $\mathbf{2}$ & $\mathbf{4}$ & $\mathbf{6}$ & $\mathbf{8}$ & $\mathbf{1 0}$ \\
\hline Relative cooling $\operatorname{cost}\left(r e v c_{k}\right)$ & 1 & 0.80 & 0.64 & 0.50 & 0.38 \\
\hline
\end{tabular}

It is assumed in this study that all transportation operations between cities are made by unique middlesized trucks. It is considered that these trucks consume 20 liters fuel in $100 \mathrm{~km}(0.2$ liters in $1 \mathrm{~km})$. In addition, it is considered that cost of 1 liter fuel is $6.5 \mathrm{TL}$. Therefore, it is assumed that the fuel cost for 0.2 liter, which means $1 \mathrm{~km}$, is $1.3 \mathrm{TL}$. Considering this assumption, the fuel cost of transportation $\left(f c_{i, j}\right)$ is evaluated by multiplying the distance $(\mathrm{km})$ values between cities and $1.3 \mathrm{TL}$. The fuel cost of transportation $\left(f c_{i, j}\right)$ between production and retailer cities and related distances $(\mathrm{km})$ [23] $\left(\right.$ dist $\left._{i, j}\right)$ are represented in Table 12.

Table 12. Distances $(\mathrm{km})$ and fuel cost of transportation $(T L)$ between cities

\begin{tabular}{lcccccccc}
\hline & & \multicolumn{2}{c}{ Distances $(\mathbf{k m})$} & \multicolumn{4}{c}{ Fuel cost of transportation $(\boldsymbol{T L})$} \\
& Ankara & İstanbul & Bursa & İzmir & Ankara & İstanbul & Bursa & İzmir \\
\hline Adana & 490 & 939 & 839 & 900 & 637 & $1,220.70$ & $1,090.70$ & 1,170 \\
\hline Antalya & 544 & 718 & 541 & 444 & 707.20 & 933.40 & 703.30 & 577.20 \\
\hline Artvin & 980 & 1,301 & 1,312 & 1,559 & 1274 & $1,691.30$ & $1,705.60$ & $2,026.70$ \\
\hline Aydın & 598 & 984 & 445 & 126 & 777.40 & $1,279.20$ & 578.50 & 163.80 \\
\hline Balkesir & 535 & 390 & 151 & 176 & 695.50 & 507 & 196.30 & 228.80 \\
\hline Burdur & 422 & 596 & 419 & 374 & 548.60 & 774.80 & 544.70 & 486.20 \\
\hline Giresun & 608 & 929 & 940 & 1,187 & 790.40 & $1,207.70$ & 1,222 & $1,543.10$ \\
\hline Hatay & 681 & 1,130 & 1,030 & 1,091 & 885.30 & 1,469 & 1,339 & $1,418.30$ \\
\hline Kahramanmaraş & 591 & 1,044 & 964 & 1,092 & 768.30 & $1,357.20$ & $1,253.20$ & $1,419.60$ \\
\hline Kastamonu & 243 & 510 & 521 & 822 & 315.90 & 663 & 677.30 & $1,068.60$ \\
\hline Mersin & 483 & 932 & 831 & 892 & 627.90 & $1,211.60$ & $1,080.30$ & $1,159.60$ \\
\hline Muğla & 620 & 783 & 544 & 225 & 806 & $1,017.90$ & 707.20 & 292.50 \\
\hline Ordu & 564 & 885 & 896 & 1,143 & 733.20 & $1,150.50$ & $1,164.80$ & $1,485.90$ \\
\hline Osmaniye & 577 & 1,026 & 926 & 987 & 750.10 & $1,333.80$ & $1,203.80$ & $1,283.10$ \\
\hline Rize & 819 & 1,140 & 1,151 & 1,398 & $1,064.70$ & 1482 & $1,496.30$ & $1,817.40$ \\
\hline Trabzon & 744 & 1,065 & 1,076 & 1,323 & 967.20 & $1,384.50$ & $1,398.80$ & $1,719.90$ \\
\hline İzmir & 579 & 564 & 325 & 0 & 752.70 & 733.20 & 422.50 & 0 \\
\hline
\end{tabular}

It is assumed that these mid-size trucks can consume a maximum of $125 \mathrm{~km}$ in a day. By this assumption and the distance data in Table 12, the number of periods (year) in which transportation last between cities is evaluated. Table 13 shows the number of periods (year) that transportation last between cities.

Table 13. Number of periods (year), which transportation last between cities

\begin{tabular}{lcccc}
\hline & Ankara & İstanbul & Bursa & İzmir \\
\hline Adana & 0.01 & 0.02 & 0.01 & 0.01 \\
\hline Antalya & 0.01 & 0.01 & 0.01 & 0.00 \\
\hline Artvin & 0.02 & 0.02 & 0.02 & 0.03 \\
\hline Aydin & 0.01 & 0.02 & 0.00 & 0.00 \\
\hline Balıkesir & 0.01 & 0.00 & 0.00 & 0.00 \\
\hline Burdur & 0.00 & 0.01 & 0.00 & 0.00 \\
\hline
\end{tabular}


Table 13. (cont.) Number of periods (year), which transportation last between cities

\begin{tabular}{lllll}
\hline Giresun & 0.01 & 0.02 & 0.02 & 0.02 \\
\hline Hatay & 0.01 & 0.02 & 0.02 & 0.02 \\
\hline Kahramanmaraş & 0.01 & 0.02 & 0.02 & 0.02 \\
\hline Kastamonu & 0.00 & 0.01 & 0.01 & 0.01 \\
\hline Mersin & 0.01 & 0.02 & 0.01 & 0.01 \\
\hline Muğla & 0.01 & 0.01 & 0.01 & 0.00 \\
\hline Ordu & 0.01 & 0.01 & 0.01 & 0.02 \\
\hline Osmaniye & 0.01 & 0.02 & 0.02 & 0.02 \\
\hline Rize & 0.01 & 0.02 & 0.02 & 0.03 \\
\hline Trabzon & 0.01 & 0.02 & 0.02 & 0.02 \\
\hline İzmir & 0.01 & 0.01 & 0.00 & 0.00 \\
\hline
\end{tabular}

It is assumed in this study that the waste disposal cost for unit product is $30 \mathrm{TL}$ for each city. In addition, ten times of the electrical energy cost at each temperature is considered as a daily cost for production and storage for each city.

\section{RESULTS AND DISCUSSIONS}

The model is solved in GAMS 24.1.3 by CPLEX solver. The test runs are performed on a $3.20 \mathrm{GHz}$ Intel ${ }^{\circledR}$ Core ${ }^{\mathrm{TM}}$ i5-3470 PC (with 4.00 GB RAM). The resulting solution is proven optimal with 1.08 second CPLEX solution time. The mixed integer programming (MIP) solution has 1,539 iterations. The MIP and best possible solution value is $12,141,989,489,863$. The absolute and relative gaps are zero. The MIP has a total of 49,189 rows, 6,613 columns. Because the objective value is the cumulative sum of the total cost of supply chain processes of cities and consumers for 6 years, the resulting values are relatively large. Table 14 shows the assigned transportation arcs indicating producer/distributer cities, retailer cities, temperatures and periods for the optimal solution. The assigned arcs are represented by "x" symbols.

Table 14. The assigned transportation arcs

\begin{tabular}{|c|c|c|c|c|c|c|c|c|}
\hline Producer/Distributor & Retailer/Distributer & Temperature & 2020 & 2021 & 2022 & 2023 & 2024 & 2025 \\
\hline Ankara & İstanbul & 8 & $\mathrm{x}$ & & & & $\mathrm{X}$ & $\mathrm{x}$ \\
\hline Ankara & İstanbul & 6 & & $\mathrm{x}$ & $\mathrm{x}$ & & & \\
\hline Ankara & İstanbul & 4 & & & & $\mathrm{x}$ & & \\
\hline Antalya & İstanbul & 10 & $\mathrm{X}$ & $\mathrm{x}$ & $\mathrm{x}$ & $\mathrm{x}$ & $\mathrm{x}$ & $\mathrm{X}$ \\
\hline Balikesir & İstanbul & 10 & $\mathrm{x}$ & $\mathrm{x}$ & $\mathrm{x}$ & $\mathrm{x}$ & $\mathrm{x}$ & $\mathrm{X}$ \\
\hline Mersin & İstanbul & 10 & $\mathrm{x}$ & $\mathrm{x}$ & $\mathrm{x}$ & $\mathrm{x}$ & $\mathrm{x}$ & $\mathrm{x}$ \\
\hline Adana & Ankara & 2 & $\mathrm{X}$ & $\mathrm{x}$ & $\mathrm{x}$ & $\mathrm{x}$ & $\mathrm{x}$ & $\mathrm{X}$ \\
\hline Antalya & Ankara & 4 & $\mathrm{x}$ & $\mathrm{x}$ & $\mathrm{x}$ & $\mathrm{x}$ & $\mathrm{x}$ & $\mathrm{x}$ \\
\hline Artvin & Ankara & 10 & $\mathrm{x}$ & $\mathrm{x}$ & $\mathrm{x}$ & $\mathrm{x}$ & $\mathrm{x}$ & $\mathrm{x}$ \\
\hline Burdur & Ankara & 10 & & & & $\mathrm{x}$ & $\mathrm{x}$ & $\mathrm{x}$ \\
\hline Hatay & Ankara & 10 & $\mathrm{X}$ & $\mathrm{x}$ & & $\mathrm{x}$ & $\mathrm{x}$ & \\
\hline Kahramanmaraş & Ankara & 10 & $\mathrm{x}$ & $\mathrm{x}$ & $\mathrm{x}$ & $\mathrm{x}$ & $\mathrm{x}$ & $\mathrm{x}$ \\
\hline Kastamonu & Ankara & 10 & $\mathrm{X}$ & $\mathrm{x}$ & $\mathrm{x}$ & $\mathrm{X}$ & $\mathrm{X}$ & $\mathrm{x}$ \\
\hline Giresun & Ankara & 10 & $\mathrm{x}$ & $\mathrm{x}$ & $\mathrm{x}$ & $\mathrm{x}$ & $\mathrm{x}$ & $\mathrm{x}$ \\
\hline Ordu & Ankara & 10 & $\mathrm{x}$ & $\mathrm{x}$ & $\mathrm{x}$ & $\mathrm{x}$ & $\mathrm{x}$ & $\mathrm{x}$ \\
\hline Rize & Ankara & 10 & $\mathrm{x}$ & $\mathrm{x}$ & $\mathrm{x}$ & $\mathrm{x}$ & $\mathrm{x}$ & $\mathrm{x}$ \\
\hline Trabzon & Ankara & 10 & $\mathrm{x}$ & $\mathrm{x}$ & $\mathrm{x}$ & $\mathrm{x}$ & $\mathrm{x}$ & $\mathrm{x}$ \\
\hline Balıkesir & Bursa & 10 & $\mathrm{x}$ & $\mathrm{x}$ & $\mathrm{x}$ & $\mathrm{x}$ & $\mathrm{x}$ & $\mathrm{x}$ \\
\hline İzmir & Bursa & 10 & $\mathrm{X}$ & $\mathrm{x}$ & $\mathrm{x}$ & $\mathrm{x}$ & $\mathrm{x}$ & $\mathrm{X}$ \\
\hline Aydın & İzmir & 2 & $\mathrm{X}$ & $\mathrm{x}$ & $\mathrm{x}$ & $\mathrm{x}$ & $\mathrm{x}$ & $\mathrm{X}$ \\
\hline Balıkesir & İzmir & 4 & $\mathrm{X}$ & $\mathrm{x}$ & $\mathrm{x}$ & $\mathrm{x}$ & $\mathrm{X}$ & $\mathrm{X}$ \\
\hline Muğla & İzmir & 6 & $\mathrm{x}$ & $\mathrm{X}$ & $\mathrm{x}$ & $\mathrm{x}$ & $\mathrm{x}$ & $\mathrm{X}$ \\
\hline İzmir & İzmir & 2 & $\mathrm{X}$ & $\mathrm{X}$ & $\mathrm{x}$ & $\mathrm{x}$ & $\mathrm{X}$ & $\mathrm{X}$ \\
\hline
\end{tabular}


From Table 14 , it is shown that the temperature mostly has the highest level $\left(10^{\circ} \mathrm{C}\right)$ between cities. It is shown that when the distance decreases, the cooler temperatures are used during transportation. One of the probable reason is the distances between producer and retailer cities are very high. In addition, there are not many distributor cities between them. Because the cooling cost is very dependent on the distance per $\mathrm{km}$, the mentioned reasons prevent the cooler transportation and decrease the food quality. Another probable reason is, besides the suggested mathematical model tries to protect higher quality for products by the constraints, it does not force the model enough. To prevent this situation, the mathematical model can be modified by considering the product quality more. For instance, there can be additional constraints or penalty costs that occur when the product quality decreases in the objective function.

\section{CONCLUSIONS}

In this study, the orange supply chain processes of cities in Turkey are analyzed for future 6 years period. It is considered that a total of 17 producer, 2 distributer, and 4 retailer cities in the supply chain network. The purpose of the suggested model is minimizing the total costs in the supply chain processes including production, storage, and transportation costs. These costs are considered by cooling costs for different temperatures. In addition, consumer costs are considered and minimized for each city and year in this study. Considering the managerial functions of the food supply chain, it is very significant to minimize all of the probable costs and protecting higher product quality at the same time. The solution methodology suggested in this study considers these purposes. By this way, the cost and product quality elements of the supply chain are integrated and the management operations for the food supply chain become more comprehensive. The decision-makers can use this methodological approach to make complex management tasks easier. The results of the case study validate that the suggested model in this study makes considerable improvement in the results and solution time. In addition, the suggested model is adaptable for different types of food supply chains. It is aimed in this study that the suggested solution approach can be a source of inspiration for related optimization problems.

In future studies, some accepted assumptions to forecast future data can be developed by different approaches. For example, the producer and consumer costs are forecasted by trend analysis using linear trend model. However, to get more realistic data, some other factors such as forecasts about the country economics for future years by the support of experts or other resources can be considered. In addition, the forecasted population of the retailer cities are estimated by the same trend analysis method. However, some factors such as the forecasted population growth rate and internal and external migration of the cities can also be considered. The forecasted production amounts are estimated by the non-seasonal ARIMA model and the optimal parameters are determined for each city. In future studies, different forecasting approaches can be implemented for the sensitivity analysis. Therefore, the forecasted values can be compared and the optimal forecasting technique can be determined. In addition, the forecasts about future production capacities of the cities can also be considered. In this way, the procured outputs for the future years can be more instructive about the real-life problem. A comprehensive simulation experiment can also be implemented to the considered problem to analyze the future production and demand of the cities. Finally, the cooling costs for different temperatures are estimated by assuming different ratios of the system efficiencies and these ratios are multiplied with the $C P$ values. However, the cooling costs can be calculated by considering more factors such as mechanical/electrical properties of the cooling equipment effecting the cooling processes to get exact cooling costs for the different temperatures.

\section{REFERENCES}

[1] D.P. Van Donk, R. Akkerman and T. VanderVaart, "Opportunities and realities of supply chain integration: The case of food manufacturers," British Food Journal, vol. 110, pp. 218-235, 2018. 
[2] D. Smith and L. Sparks, "Temperature controlled supply chains," in Food Supply Chain Management, M.A. Bourlakis and P.W.H. Weightman, Eds., Oxford, U.K.: Blackwell Publishing, 2004, pp. $179-198$.

[3] R. Manzini, R. Accorsi, Z. Ayyad, A. Bendini, M. Bortolini, G. Gamberi, E. Valli and T.G. Toschi, "Sustainability and quality in the food supply chain. A case study of shipment of edible oils," British Food Journal, vol. 116, pp. 2069-2090, 2014.

[4] J. Trienekens and P. Zuurbier, "Quality and safety standards in the food industry, developments and challenges," International Journal of Production Economics, vol. 113, pp. 107-122, 2008.

[5] M. Lütke Entrup, H.O. Günther, P. VanBeek, M. Grunow and T. Seiler, "Mixed-integer linear programming approaches to shelf-life-integrated planning and scheduling in yoghurt production," International Journal of Production Research, vol. 43, pp. 5071-5100, 2005.

[6] F. Sgarbossa and I. Russo, "A proactive model in sustainable food supply chain: Insight from a case study," International Journal of Production Economics, vol. 183, pp. 596-606, 2017.

[7] D. Zilberman, L. Lu and T. Reardon, "Innovation-induced food supply chain design," Food Policy, vol. 83, pp. 289-297, 2019.

[8] H. Allaoui, Y. Guo, A. Choudhary. and J. Bloemhof, "Sustainable agro-food supply chain design using two-stage hybrid multi-objective decision-making approach," Computers and Operations Research, vol. 89, pp. 369-384, 2018.

[9] A. Rong, R. Akkerman and M. Grunow, "An optimization approach for managing fresh food quality throughout the supply chain," International Journal of Production Economics, vol. 131, pp. 421429, 2011.

[10] M.M. Aung and Y.S. Chang, "Traceability in a food supply chain: safety and quality perspectives," Food Control, vol. 39, pp. 172-184, 2014.

[11] R. Manzini and R. Accorsi, "The new conceptual framework for food supply chain assessment," Journal of Food Engineering, vol. 115, pp. 251-263, 2013.

[12] M. Yu and A. Nagurney, "Competitive food supply chain networks with application to fresh produce," European Journal of Operational Research, vol. 224, pp. 273-282, 2013.

[13] M.M. Aung and Y.S. Chang, "Temperature management for the quality assurance of a perishable food supply chain," Food Control, vol. 40, pp. 198-207, 2014.

[14] A. Diabat, K. Govindan and V.V. Panicker, "Supply chain risk management and its mitigation in a food industry," International Journal of Production Research, vol. 50, pp. 3039-3050, 2012.

[15] Republic of Turkey Ministry of Agriculture and Forestry, Agricultural Economic and Policy Development Institute. (2020, January). Tartm Ürünleri Piyasalart [Online]. Available: https://arastirma.tarimorman.gov.tr/tepge/Belgeler/PDF\%20Tar\%C4\%B1m\%20\%C3\%9Cr\%C3\%BCn leri\%20Piyasalar\%C4\%B1/2020Ocak\%20Tar\%C4\%B1m\%20\%C3\%9Cr\%C3\%BCnleri\%20Raporu/P ortakal\%20Tar\%C4\%B1m\%20\%C3\%9Cr\%C3\%BCnleri\%20Piyasa\%20Raporu\%202020\%20ocak.pd $\mathrm{f}$

[16] Merkezi Dağıtım Sistemi dataset: Concatenated, 2014 to 2019, TÜİK (Turkish Statistical Institute), Aug. 2020. [Online]. Available: https://biruni.tuik.gov.tr/medas/?kn=104\&locale=tr 
[17] R. H. Shumway and D. S. Stoffer, "Time series regression and ARIMA models," in Time Series Analysis and Its Applications, New York, U. S.: Springer, 2000, pp. 89-212.

[18] P. S. P. Cowpertwait and A. V. Metcalfe, "Non-seasonal ARIMA models," in Introductory Time Series with R, New York, U. S.: Springer, 2009, pp. 134-141.

[19] Republic of Turkey Ministry of Agriculture and Forestry, Agricultural Economic and Policy Development Institute. (2019, July). Tarım Ürünleri Piyasalarl [Online]. Available: https://arastirma.tarimorman.gov.tr/tepge/Belgeler/PDF\%20Tar\%C4\%B1m\%20\%C3\%9Cr\%C3\%BCn leri\%20Piyasalar\%C4\%B1/2019Temmuz\%20Tar\%C4\%B1 m\%20\%C3\%9Cr\%C3\%BCnleri\%20Rapor u/2019-Temmuz\%20Portakal.pdf

[20] Republic of Turkey Ministry of Agriculture and Forestry, Agricultural Economic and Policy Development Institute. (2020, July). Tarım Ürünleri Piyasalarl [Online]. Available: https://arastirma.tarimorman.gov.tr/tepge/Belgeler/PDF\%20Tar\%C4\%B1m\%20\%C3\%9Cr\%C3\%BCn leri\%20Piyasalar\%C4\%B1/2020Temmuz\%20Tar\%C4\%B1m\%20\%C3\%9Cr\%C3\%BCnleri\%20Rapor u/Portakal,\%20Temmuz2020,\%20Tar\%C4\%B1m\%20\%C3\%9Cr\%C3\%BCnleri\%20Piyasa\%20Rapor u.pdf

[21] Adrese Dayalı Nüfus Kaylt Sistemi dataset: Concatenated, 2014 to 2019, TÜiK (Turkish Statistical Institute), Aug. 2020. [Online]. Available: http://www.tuik.gov.tr/PreTablo.do?alt_id=1059

[22] S.K. Wang, Handbook of Air Conditioning and Refrigeration, 2nd ed. New York, NY, USA: McGraw-Hill, 2001.

[23] Distance Calculator dataset, Republic of Turkey General Directorate of Highways, Aug. 2020. [Online]. Available: https://www.kgm.gov.tr/Sayfalar/KGM/SiteTr/Uzakliklar/illerArasiMesafe.aspx 